\title{
Significance and prognosis of an isolated late systolic murmur: a 9- to 22-year follow-up ${ }^{1}$
}

\author{
Howard Allen, Alan Harris, and Aubrey Leatham \\ From St. George's Hospital, London
}

Sixty-two patients with an isolated late systolic murmur, of whom 33 had a systolic click also, have been followed for a minimum of 9 years (mean 13.8, maximum 22 years). Most had been known to have a murmur for much longer (mean 27 years, maximum $5 I$ years). They were all thought to have mitral regurgitation that was minimal and primary and not secondary to myocardial disease or ischaemic heart disease. Patients were excluded from the series if there were more than minimal left atrial or left ventricular enlargement on $x$-ray, an abnormal electrocardiogram apart from multiple ventricular ectopics and succeeding flat $T$ waves, or $a$ history of chest pain closely associated with exertion.

Four could not be traced but had not been certified as dead at Somerset House, 3 died from irrelevant causes, I died from bacterial endocarditis, and I died I I years later aged 75 from increasing mitral regurgitation.

In I patient there was chordal rupture necessitating valve replacement and in I patient bacterial endocarditis caused heart failure.

In 10 patients there was slight deterioration, short of the development of symptoms, over a period averaging II years.

In $4 I$ patients there was no deterioration over an average of 13.8 years.

Thus the prognosis for a patient with a late systolic murmur as the only abnormal sign is good apart from the risk of bacterial endocarditis ( 5 cases). There is no justification for the belief that ventricular ectopics in these patients are dangerous and that sudden death occurs, provided that care is taken to exclude patients with myocardial or ischaemic heart disease.

Systolic murmurs which are loudest in the mitral area and have a crescendo in late systole continuing to aortic closure, have aroused much interest in the past 20 years. Though formerly regarded as evidence of mitral regurgitation (Griffith, 1892; Hall, 1903), in the absence of other physical signs they were regarded as innocent by Evans (1943), not always innocent by D. E. Bedford (1945, personal communication), and as indicating slight mitral regurgitation by Wood (1950) and by Miller and Wedum (1949) because of their occurrence during the course of acute rheumatic carditis. Two of 30 cases with postmortem or radiological evidence of mitral regurgitation had late systolic murmurs, and a crescendo in late systole was found to be a feature of the murmur of mitral regurgitation (Brigden and Leatham, 1953). It had been thought by one of us, however, that a murmur confined to late systole

Received 12 November 1973.

1 Presented to the British Cardiac Society, November 1972. without any other abnormality and without pansystolic vibrations on the phonocardiogram might be exocardial, but with improvement in phonocardiographic techniques, pansystolic vibrations could be recorded in almost all cases (Fig. I and 2) consistent with mitral regurgitation. Furthermore, the pattern of the murmur was identical with those with other evidence of mitral valve disease, and slight enlargement of the left atrium with systolic expansion could be detected on $x$-ray screening in the anterior view in about half the cases. Most cardiologists came to hold the view that a late systolic murmur with or without a systolic click was always caused by mitral regurgitation; this has now been confirmed by angiocardiography (Barlow et al., 1963; Criley et al., 1966). Moreover, there is a close association between a late systolic murmur and a minimal degree of mitral regurgitation as shown by the absence of left ventricular hypertrophy or enlargement and no more than minimal left atrial 


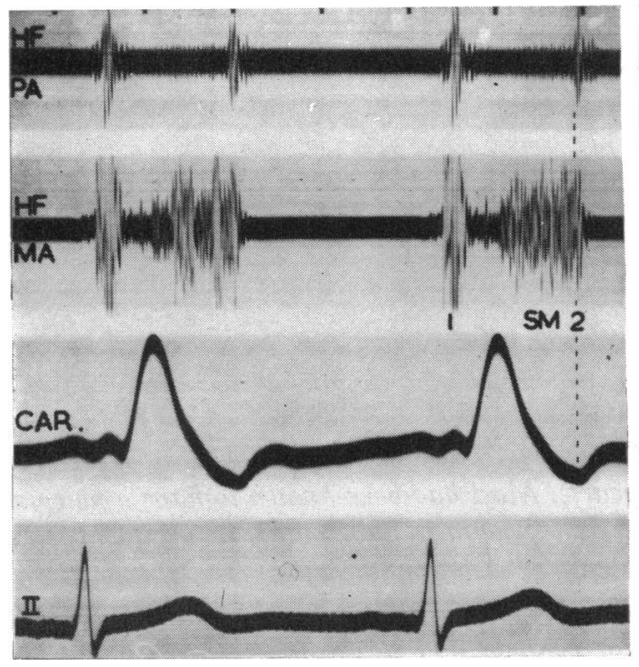

A

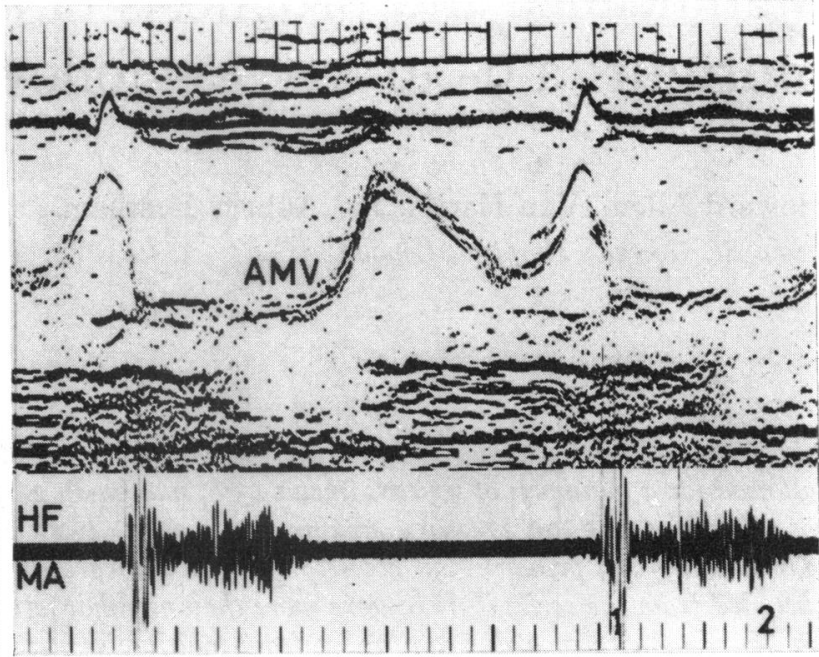

B

FIG. I High frequency phonocardiograms $(H F)$ resembling auscultation, recorded in the pulmonary area $(P A)$ and in the mitral area $(M A)$ from V.B. (Table 4), A) in 1955 (aged $42-$ murmur since aged 5) and B) in 1973 showing a late systolic murmur with little change. In nearly all cases pansystolic vibrations can be recorded, but the bulk of the murmur is in late systole and maximal at the mitral area where it drowns the aortic component of the second sound and a simultaneous tracing from the pulmonary area is required to show that the murmur is pansystolic. In 1973 the patient was free of symptoms except for occasional paroxysms of atrial fibrillation requiring DC reversion. No history of rheumatic fever and no mitral prolapse on the echocardiogram (courtesy of Graham Leech, AMV=aortic cusp of mitral valve). No systolic click was heard.

enlargement on $x$-ray. Over the past 20 years we have only seen two possible exceptions to this rule as disclosed by cineangiocardiography. Even minimal mitral regurgitation may of course be the result of myocardial or ischaemic heart disease, but an attempt has been made to exclude these causes by excluding patients with a history of cardiac pain or dyspnoea, cardiac enlargement on $x$-ray, or an abnormal electrocardiogram. Many of the patients in the study, however, had ventricular ectopics, often multiple, and this is known to be a frequent finding in patients with mitral regurgitation (Brigden and Leatham, 1953); flat or slightly inverted T waves in succeeding beats (Fig. 3) did not exclude them from the study since these changes were regarded as the direct result of the preceding ectopic and akin to the effect of pacing (Chatterjee et al., 1969) or paroxysmal tachycardia.

Even though we are left with patients with evidence of only a minimal abnormality confined to the mitral valve which would be expected to be 'floppy' or rheumatic, previous reports have suggested that the prognosis is uncertain, with sudden death from dysrhythmia as a possibility (Hancock and Cohn, 1966; Barlow et al., 1968). A long-term follow-up has, therefore, been made consisting mainly of patients in whom a clinical and phonocardiographic examination had been made by one of us at the National Heart Hospital in the early 1950's. The object of the survey is to help the physician to make a prognosis when he encounters a patient with isolated slight mitral regurgitation.

\section{Subjects and method}

The phonocardiographic day-books at the National Heart and St. George's Hospitals were searched and all cases with isolated late systolic murmurs recorded between 1950 and 1963 were included in this survey. Many had palpitation and chest pain and evidence of an anxiety state but they were excluded if there was a history of cardiac pain or infarction, more than minimal left atrial or left ventricular enlargement on $x$-ray, or if there was an electrocardiographic abnormality other than ectopic beats with ensuing flat T waves (Fig. 3). Multiple ventricular ectopics were recorded in Io cases but all were in sinus rhythm. Patients with evidence of involvement 


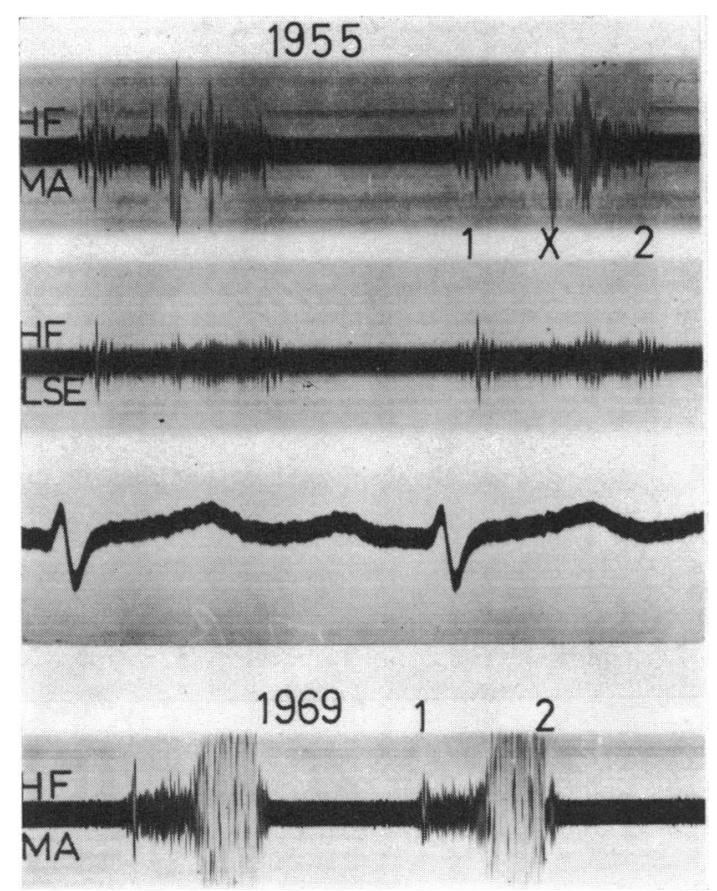

FIG. 2 Phonocardiograms recorded from F.C. (Table 2) in 1955 (aged 66) and in 1969. The late systolic murmur was preceded by a click which was no longer present in 1969 when he was free of symptoms without cardiac enlargement on $\mathrm{x}$-ray. He died 4 years later aged 82 from bronchopneumonia following an embolectomy, soon after the onset of atrial fibrillation which was otherwise well tolerated.

of other valves or with systemic hypertension were excluded. Marfan's syndrome was included if there were no other cardiovascular abnormality.

All patients presenting to us as isolated slight mitral regurgitation were included in this survey if a phonocardiogram had been recorded more than 9 years previously, and in the majority a murmur had been known to be present much longer. These criteria were fulfilled in 62 cases, in 33 of whom there were mid or late systolic clicks in addition to a murmur (Fig. 2 and 5). Those with a mid or late systolic click alone and no murmur even in the left lateral position were not included. Most patients had been referred because of the murmur, or because of palpitation from ventricular ectopics (33 cases). There were 34 men and 28 women, with ages ranging from 7 to 71 years (mean 38 ) when first seen. There was a history of rheumatic fever in 14 cases and overt Marfan's syndrome was present in 2.

\section{Results}

The follow-up was successful in 58 of the 62 cases (Table I). The remaining 4 cases could not be traced but are likely to be alive since 'searches' at Somerset House in 1968 and in 1971 revealed their birth certificates but no record of death. There is still, however, a possibility of emigration and death.

The 58 patients were recalled in 1968 and the phonocardiogram, electrocardiogram, and $x$-ray were repeated in every case. The minimum follow-

TABLE I 62 cases: isolated late systolic murmur followed for 9 to 22 years

$\begin{aligned} 4 & \text { Lost to follow-up } \\ 5 & \text { Deaths } \\ 2 & \text { Great deterioration } \\ \text { IO } & \text { Slight deterioration } \\ \text { 4I } & \text { No deterioration }\end{aligned}$

up was then 5 years and they were requestioned by post in 1972 giving a minimum period of observation of 9 years, though in most it was longer (mean I4 years), and the maximum was 22 years. The history of a murmur often extended further back and averaged 26.8 years, reaching $5 \mathrm{I}$ years in one case and 49 years in another. Many cases had been followed up at regular intervals giving further information between the 2 obligatory examinations.

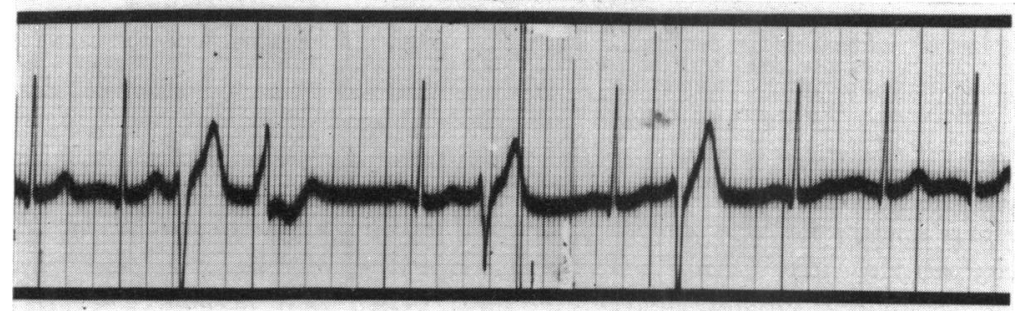

FIG. 3 Electrocardiogram in a 50-year-old woman without symptoms showing multiple ventricular ectopics. No change between 1963 and 1972. 


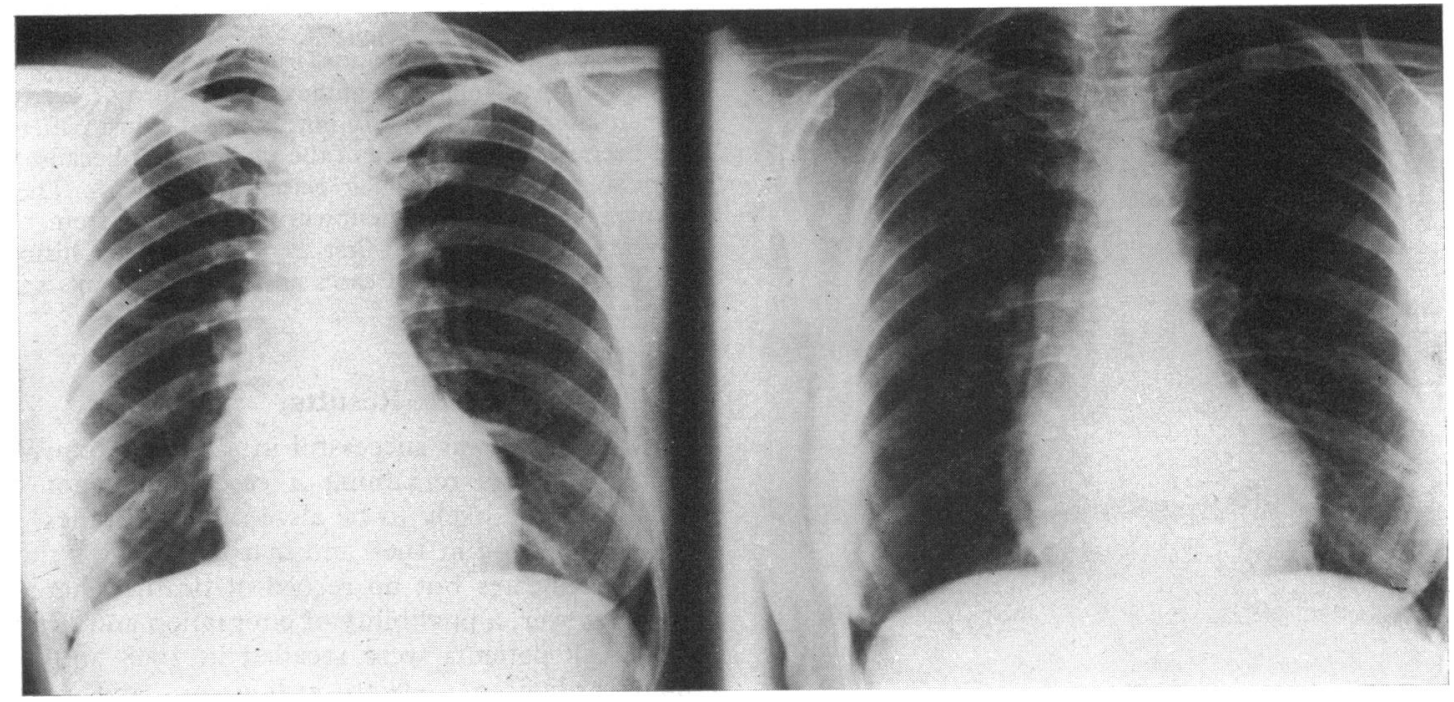

FIG. 4 No change in heart size over 17 years in one of the patients with no deterioration.

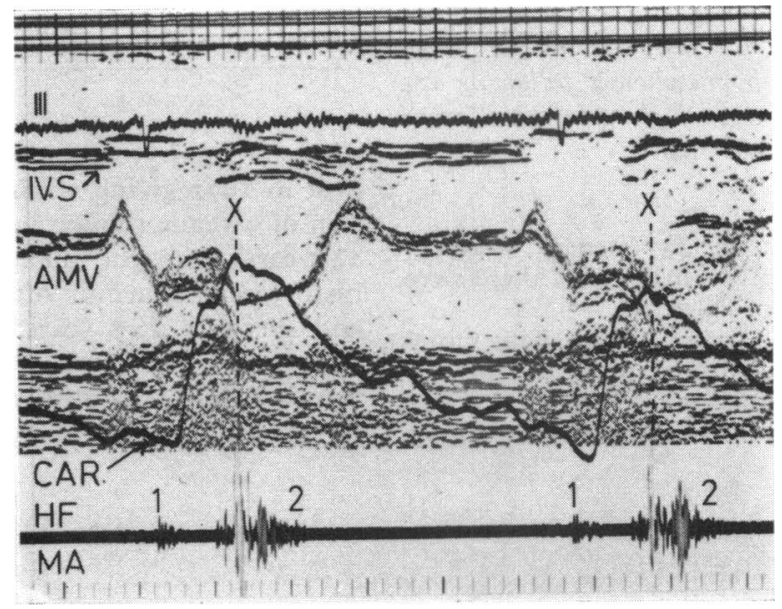

FIG. 5 Echocardiogram in F.S. (Table 4) recorded in 1973 showing prolapse of both mitral cusps in association with a click and a late systolic murmur. The click and murmur had been first noticed in 1948 and in 1966 he suffered cardiac infarction. He was assessed by coronary arteriography because of confusing symptoms and found to have obstruction of his anterior descending coronary artery; the other vessels were normal. The ventriculogram showed minimal mitral regurgitation and prolapsing cusps, haemodynamics were normal, and the development of coronary disease was regarded as incidental. The echo (courtesy of Graham Leech) shows that halting of posterior movement of both mitral cusps coincides with the click. 
TABLE 25 deaths

\begin{tabular}{|c|c|c|c|c|c|}
\hline & Sex & $\begin{array}{l}\text { Age murmur } \\
\text { first known } \\
(y r)\end{array}$ & $\begin{array}{l}\text { Age first } \\
\text { seen } \\
(y r)\end{array}$ & Follow-up & Age, death, findings \\
\hline M.P. & $\mathbf{F}$ & $2 I$ & 48 & $\begin{array}{l}\text { Angina; } \\
\text { cholesterol } 437 \mathrm{mg} / 100 \mathrm{ml}\end{array}$ & $\begin{array}{l}53 \text { years; necropsy; } \\
\text { cerebral haemorrhage, } \\
\text { hypertension, } \\
\text { chronic rheumatic mitral } \\
\text { valve disease }\end{array}$ \\
\hline H.S. & $\mathbf{M}$ & 60 & 60 & 一 & $\begin{array}{l}65 \text { years; necropsy; } \\
\text { ruptured mycotic aneurysm, } \\
\text { bacterial endocarditis on } \\
\text { mitral valve }\end{array}$ \\
\hline P.M. & $\mathbf{M}$ & 47 & 47 & $\begin{array}{l}58 \text { years; } \\
\mathrm{BP}=180 / \text { I } 10 \mathrm{mmHg} ; \\
\text { left bundle-branch block }\end{array}$ & $\begin{array}{l}59 \text { years; no necropsy; } \\
\text { chest pain, } \\
\text { infarct clinically }\end{array}$ \\
\hline S.B. & $\mathbf{M}$ & 63 & 63 & $\begin{array}{l}74 \text { years; } \\
\text { atrial fibrillation; } \\
\text { pansystolic murmur; } \\
\text { BP I } 70 / 100 \text { mmHg; } \\
\text { heart }++ \text { on } x \text {-ray; } \\
\text { symptoms of failure }\end{array}$ & $\begin{array}{l}75 \text { years; no necropsy; } \\
\text { died abroad }\end{array}$ \\
\hline F.C. & $\mathbf{M}$ & 65 & 66 & $\begin{array}{l}78 \text { years; } \\
\text { no deterioration; } \\
\text { small heart on } x \text {-ray }\end{array}$ & $\begin{array}{l}82 \text { years; no necropsy; } \\
\text { atrial fibrillation, } \\
\text { systemic embolism, } \\
\text { died - bronchopneumonia post } \\
\text { embolectomy }\end{array}$ \\
\hline
\end{tabular}

Five patients died and the details are given in Table 2. There were necropsies in 3 of them, but unfortunately the mitral valve was not described in great detail. Two of the deaths appear unrelated to the mitral regurgitation, one certainly so (M.P.), and in the other (P.M.) the doctor informed us that an attack of chest pain followed by death was so typical of infarction that he did not request a necropsy, and this had been preceded by the development of hypertension and left bundle-branch block I I years after the first examination. One patient (H.S.) died of bacterial endocarditis. In I patient (S.B.) the mitral regurgitation increased and this occurred at the age of 74 years after I I years of observation, and was probably due to the onset of atrial fibrillation: hypertension may have been a factor ( $170 / 100$ $\mathrm{mmHg})$ and there was left axis deviation $\left(-40^{\circ}\right)$ : there was no necropsy. In one patient (F.C., Fig. 2) death at 82 years was attributed to broncho- pneumonia following embolectomy, there having been no deterioration beforehand.

In 2 patients there was great deterioration (Table 3). M.N. developed bacterial endocarditis and heart failure 14 years after his first visit, having been known to have a heart murmur for 17 years. L.N. suddenly developed left ventricular failure at the age of 58, 2 years after his first visit and having been known to have a murmur for 29 years; his heart failure resisted medical therapy and 3 months later the valve was replaced by a Starr valve; at the operation there was pronounced redundancy of the posterior leaflet and its central chordae had ruptured.

In Io patients (Table 4 ) there was some deterioration but short of symptoms and short of heart failure. The commonest change was slight cardiac enlargement on $x$-ray often accompanied by a change to a more evenly pansystolic murmur, over

TABLE 32 cases: great deterioration

\begin{tabular}{llllll}
\hline & Sex & $\begin{array}{l}\text { Age murmur } \\
\text { first known }(y r)\end{array}$ & $\begin{array}{l}\text { Age first } \\
\text { seen }(y r)\end{array}$ & $\begin{array}{l}\text { Age }(y r) \\
\text { heart failure }\end{array}$ & Findings \\
\hline M.N. & M & 19 & 22 & 36 & $\begin{array}{l}\text { Bacterial endocarditis } \\
\text { Sudden left ventricular failure, } \\
\text { ruptured chordae, } \\
\text { Starr valve }\end{array}$ \\
\hline
\end{tabular}


TABLE 4 IO cases: slight deterioration

\begin{tabular}{|c|c|c|c|c|c|c|}
\hline & $\begin{array}{l}\text { Age murmur } \\
\text { first known }\end{array}$ & Sex & $\begin{array}{l}\text { Age first } \\
\text { seen }\end{array}$ & $\begin{array}{l}\text { Age } \\
\text { and }\end{array}$ & $\begin{array}{l}\text { (yr) at deterioration } \\
\text { findings }\end{array}$ & $\begin{array}{l}\text { Duration ( } y r) \text { of } \\
\text { observation before }\end{array}$ \\
\hline J.B. & I7 & $\mathbf{M}$ & 22 & 40 & Heart \pm & I8 \\
\hline V.B. & 5 & $\mathbf{M}$ & 42 & 57 & Heart + , paroxysmal AF & 15 \\
\hline J.C. * & 5 & $\mathbf{F}$ & II & 14 & Heart + & 3 \\
\hline K.C. & 16 & $\mathbf{F}$ & 44 & 59 & Heart + , electrocardiogram LV + & 15 \\
\hline J.E. & 32 & $\mathbf{M}$ & 41 & 59 & $\begin{array}{l}\text { Electrocardiogram LV } \\
\text { BP } 180 / 100 \mathrm{mmHg}\end{array}$ & 18 \\
\hline R.F.* & 7 & $\mathbf{M}$ & 7 & 20 & Heart,$+ \mathrm{LV}+$, pansystolic murmur & 5 \\
\hline W.L. & 28 & $\mathbf{M}$ & 52 & 56 & AF, pansystolic murmur & 4 \\
\hline C.M. & 29 & $\mathrm{~F}$ & 47 & 56 & Heart + , atrial fibrillation & 9 \\
\hline M.N. & 54 & $\mathbf{M}$ & 54 & 64 & $\mathrm{ST} \downarrow \mathrm{V}_{5}, 7$ pansystolic murmur & 10 \\
\hline F.S. & 28 & $\mathbf{M}$ & 28 & 46 & Angina-anterior descending obstruction & 18 \\
\hline
\end{tabular}

$\star$ Marfan.

a period ranging from 3 to 18 years and averaging I I years. In only 2 cases was the deterioration pronounced, and occurring in a brief period ( 3 to 5 years), and both had obvious skeletal evidence of Marfan's syndrome. One patient (F.S., Fig. 5) developed coronary disease 18 years after his first examination and at coronary arteriography was found to have obstruction of the anterior descending artery but the circumflex and right arteries were patent; and another (J.E.) had hypertension I8 years later. In the remaining 6 cases there was deterioration without obvious cause, 4, 9, 10, 15, and 18 years later at an average age of 55 years (range 40 to 64 years) and in 3 cases coinciding with the onset of atrial fibrillation. These 6 patients gave a history of a heart murmur for an average of 26 years (range ro to $5 \mathrm{I}$ years) before deterioration.

In the remaining $4 \mathrm{I}$ cases there was no deterioration, including no cardiac enlargement on $x$-ray
(Fig. 4) over the period of observation ranging from 9 to 22 years (mean 13.8 years), and over a much longer period of known heart murmur ranging from 13 to 51 years (mean 26.8 years). Three of these patients, however, had bacterial endocarditis during this time. Eighteen of the $4 \mathrm{I}$ had systolic clicks and 9 of the $4 \mathrm{I}$ had rheumatic fever.

\section{Discussion and conclusions (Table 5)}

Observations over the years and the findings on straight $x$-ray, confirmed more recently by angiocardiography (Criley et al., 1966), leave no doubt that late systolic murmurs with or without a postejection click are caused by mitral regurgitation and that the mitral regurgitation is slight. Phonocardiography shows a characteristic late crescendo to pansystolic vibration not seen in any other condition except to a minor degree, and rarely, with small ventricular septal defects.

\section{TABLE 5 Prognosis in isolated slight mitral regurgitation}

\begin{tabular}{|c|c|c|}
\hline $\begin{array}{l}62 \\
\text { cases }\end{array}$ & $\begin{array}{l}\text { Isolated late systolic murmurs, } \\
\text { no cardiac pain, } \\
\text { normal electrocardiogram and } x \text {-ray }\end{array}$ & $\begin{array}{l}\text { Examined } \\
7 \text { to } 22 \text { years } \\
\text { before }\end{array}$ \\
\hline $\begin{array}{l}4 \\
3\end{array}$ & $\begin{array}{l}\text { Lost to follow-up } \\
\text { Deaths from other causes }\end{array}$ & \\
\hline 5 & Bacterial endocarditis & $\begin{cases}\text { I } & \text { Death } \\
\text { I } & \text { Deterioration } \\
2 & \text { No }\end{cases}$ \\
\hline $\mathbf{I}$ & Ruptured chordae & Valve replaced \\
\hline I & $\begin{array}{l}\text { Increase in mitral regurgitation over I I years } \\
\text { and died at } 75 \text { years }\end{array}$ & \\
\hline I0 & Slight deterioration & $\left\{\begin{array}{l}2 \text { Coincidental } \\
2 \text { Marfan } \\
6 \text { Pure mitral regurgitation (over average period of } 12 \\
\text { years) }\end{array}\right.$ \\
\hline $4 I$ & $\begin{array}{l}\text { No change (over average period of } 13.8 \text { years) } \\
\text { (including } 3 \text { cases of bacterial endocarditis) }\end{array}$ & \\
\hline
\end{tabular}


The mean follow-up time for the 58 patients with a late systolic murmur as the only abnormal physical sign in the cardiovascular system (2 with Marfan skeletal abnormalities) was 13.8 years (range 9 to 22 years), with a murmur known for a mean of 27 years (range 13 to $5 \mathrm{I}$ years). The main risk was the development of bacterial endocarditis and this occurred in 5 cases, one of whom died and another developed severe mitral regurgitation. There were no unexpected sudden deaths except for the one patient who had developed left bundle-branch block and hypertension 12 years later and died one year after this in a prolonged attack of chest pain thought to be due to infarction. In one patient the regurgitation increased to a serious degree over the years without bacterial endocarditis, and deterioration coincided with the onset of atrial fibrillation followed by symptoms of left ventricular failure and death abroad at the age of 75 years. In one patient there was chordal rupture and this occurred 27 years after he was informed that he had a murmur. The slight deterioration that occurred in 10 cases coincided with the onset of atrial fibrillation in 3 but was not sufficient to cause symptoms. Coincidental coronary disease developed in one patient and hypertension in another. In this group of ro cases with slight deterioration, relatively rapid changes occurred in the two with skeletal Marfan's syndrome, and also in one other coinciding with the onset of atrial fibrillation.

Thus the outlook for a patient with an isolated late systolic murmur with or without a post-ejection sound is good if bacterial endocarditis can be avoided. William Evans was nearer the truth in I943 when he described the murmur as innocent than recent authors who have hinted at a grave risk of sudden death. Barlow et al. (1968) stated that irrespective of any electrocardiographic abnormality the prognosis of patients with late systolic murmurs must remain guarded. This opinion appears to be based on one death in a patient not in their series and without careful examination of the myocardium and coronary arteries by a specialized pathologist. Furthermore, this series included patients with hypertrophic obstructive cardiomyopathy and gross electrocardiographic changes (see Fig. 8C, Barlow et al., 1968), and ischaemic heart disease, and they stressed the many different pathological states encountered. A second sudden death had been reported by Hancock and Cohn (1966) but this patient had widespread $T$ inversion suggesting myocardial or coronary disease and the necropsy was performed 'elsewhere'. In the present series an attempt has been made to include only those with evidence of an isolated abnormality of the mitral valve when first seen.
The reason for the frequent occurrence of premature beats therefore remains a puzzle, but it appears from this long-term follow-up that the risk of sudden death is remote. At the present time there are numerous instances of grave cardiac neurosis being induced in these patients by the physician. As an example, a sensible 65-year-old woman with no symptoms and a late systolic murmur had a routine medical examination in North America and was immediately admitted to a coronary care unit for the monitoring of ectopic beats and there were 2 further admissions in the next 3 months. She had had 'endocarditis' and a murmur at the age of 7 years but was free of symptoms until this medical examination, and a 'wreck' afterwards.

Reports of the pathological findings in patients with isolated late systolic murmurs are scarce, as expected from the good prognosis. Unfortunately, the 3 necropsies in this group were not performed by a pathologist interested in the finer points of cardiac pathology. It is only in the patient who suffered chordal rupture and valve replacement that we have exact observations and they indicated that the valve was 'floppy'. Others may have a minor degree of the 'floppy valve' abnormality as was indeed found by Dr. Michael Davies in one patient with a systolic click but without a murmur and therefore not in this series, who died of carcinoma of the oesophagus. Indeed the frequency of an isolated post-ejection click in routine cardiological practice is such that a benign explanation such as this is required. Ultrasonic studies may be useful in this group and prolapsed anterior and posterior mitral cusps were found in one of our cases (Fig. 5) and prolapse of the posterior cusp had been found in others (Kerber, Isaeff, and Hancock, I97I). A familial incidence has been reported (Rizzon et al., 1973) which would fit this concept. In 2 necropsied cases the aetiology was described as rheumatic and 14 of the 62 patients gave a history of rheumatic fever, so that rheumatic pathology is also probably fairly common as a cause of slight mitral regurgitation and a late systolic murmur.

Finally, it should be re-emphasized that all the patients in this series were free of cardiac symptoms when first studied and had no electrocardiographic or radiological abnormalities. Palpitation, however, was common but never disabling. Psychoneurotic symptoms and non-cardiac chest pain were frequent as emphasized by many authors in the past and as expected in patients suffering from an irregular heart beat and with knowledge of a heart murmur: the neurosis was aided in some cases by uncertainty of the diagnosis and prognosis in the mind of the physician. Many patients with late 
systolic murmurs were excluded from the series when first seen because they gave a history of angina of effort and were thought to have coronary artery disease, an expectation which proved to be correct in most cases. In others excluded from the series because of an abnormal electrocardiogram, the cause of the minimal mitral regurgitation was cardiomyopathy in its early stages. For example, a 30-year-old man had a late systolic murmur Io years before his death from diffuse cardiomyopathy and had been passed as normal, but review of the original electrocardiogram shows a flat $T$ wave in V6 without ectopic beats. Another patient with a late systolic murmur had as the only other abnormality, steep T inversion in leads II, III, and VF and the left chest leads and was thus excluded from the series, and years later proved to have hypertrophic cardiomyopathy. The much described group of patients with $T$ wave inversion in inferior leads of the electrocardiogram has not been encountered in this survey except in those cases which ultimately proved to have cardiomyopathy or coronary disease.

In conclusion, the finding of a late systolic murmur indicates the presence of mitral regurgitation and also indicates that the mitral regurgitation is slight. The presence or absence of a post-ejection sound does not seem to decide the aetiology (Barlow et al., 1968). Possible causes of the late systolic murmur are rheumatic disease of the valve, a 'floppy' valve, an ischaemic disorder of mitral valve closure, or cardiomyopathy. Review of the symptomatology and of the other physical signs and the electrocardiogram and $x$-ray should indicate whether this is an isolated abnormality of the mitral valve or whether it is secondary. If the former, a good prognosis can be given with no restriction of physical activities even in the presence of multiple ventricular extrasystoles, but the risk of bacterial endocarditis must be emphasized.

\section{References}

Barlow, J. B., Bosman, C. K., Pocock, W. A., and Marchand, P. (1968). Late systolic murmurs and non-ejection ('midlate') systolic clicks. British Heart fournal, 30, 203.
Barlow, J. B., Pocock, W. A., Marchand, P., and Denny, M. (1963). The significance of late systolic murmurs. American Heart fournal, 66, 443.

Brigden, W., and Leatham, A. (1953). Mitral incompetence. British Heart fournal, 15, 55 .

Chatterjee, K., Harris, A., Davies, G., and Leatham, A. (1969). Electrocardiographic changes subsequent to artificial ventricular depolarization. British Heart fournal, 31, 770.

Criley, J. M., Lewis, K. B., Humphries, J. O'N., and Ross, R. S. (I966). Prolapse of the mitral valve: clinical and cineangiocardiographic findings. British Heart fournal, 28, 488.

Evans, W. (1943). Mitral systolic murmurs. British Medical fournal, $\mathbf{r}, 8$.

Griffith, J. P. C. (1892). Mid-systolic and late systolic mitral murmurs. American fournal of the Medical Sciences, 104, 285.

Hall, J. N. (1903). Late systolic mitral murmurs. American fournal of the Medical Sciences, 125, 663.

Hancock, E. W., and Cohn, K. (I966). The syndrome associated with midsystolic click and late systolic murmur. American fournal of Medicine, 41, 183.

Kerber, R. E., Isaeff, D. M., and Hancock, E. W. (I97I). Echocardiographic patterns in patients with the syndrome of systolic click and late systolic murmur. New England Fournal of Medicine, 284, 691.

Miller, J. H., and Wedum, B. G. (1949). Cardiac enlargement in uncomplicated mitral insufficiency in children. American fournal of Diseases of Children, 78, 703 .

Rizzon, P., Blasco, G., Brindicci, G., and Mauro, F. (1973). Familial syndrome of midsystolic click and late systolic murmur. British Heart fournal, 35, 245.

Wood, P. (1950). Discussion on the management of rheumatic fever and its early complications: cardiac complications. Proceedings of the Royal Society of Medicine, 43, 195.

\section{Addendum}

Since this paper was written a further case report has appeared (Shappell et al., 1973).

\section{Reference}

Shappell, S. D., Marshall, C. E., Brown, R. E., and Bruce, T.A. (I973). Sudden death and the familial occurrence of mid-systolic click, late systolic murmur syndrome. Circulation, 48, 1128 .

Requests for reprints to Dr. Aubrey Leatham, St. George's Hospital, Hyde Park Corner, London SWIX ${ }_{7} \mathrm{EZ}$. 